Chirurgia (2018) 113: 780-788

No. 6, November - December

Copyright $\odot$ Celsius

http://dx.doi.org/10.21614/chirurgia.113.6.780

\title{
Management of Gastric Stromal Tumour - Multicenter Observational Study
}

\author{
Mircea Florin Costache ${ }^{1,2}$, Bogdan Filip ${ }^{1,3}$, Dragoș Viorel Scripcariu ${ }^{1,3}$, Nicolae Danilă ${ }^{1,2}$, Viorel Scripcariu ${ }^{1,3}$ \\ 'Department of Surgery, University of Medicine and Pharmacy "Gr.T. Popa" Iasi, Romania \\ ${ }^{2} 1^{\text {st }}$ Surgical Unit, "St. Spiridon" Hospital Iasi, Romania \\ ${ }^{3} 1^{\text {st }}$ Surgical Unit, Regional Institute of Oncology lasi, Romania
}

Corresponding author:

Filip Bogdan MD, PhD

1st Oncological Surgical Unit

Regional Institute of Oncology

General Henry Mathias Berthelot 2-4

lasi, Romania

E-mail: bfilip79@yahoo.com

\section{Rezumat \\ Managementul tumorilor stromale gastrice - studiu observational multicentric}

Introducere: Tumorile stromale gastrointestinale sunt unele din cele mai întalnite tumori mezenchimale ale tractului digestiv. Scopul studiului este de a evalua manifestările clinice şi tratamentul GIST-urilor gastrice.

Metodologie: Am realizat un studiu retrospectiv multicentric pe o perioadă de 5 ani condus pe o baza de date colectate prospectiv ce a inclus pacienți cu GIST gastric ce au fost operați. Am selectat pacienții cu GIST gastric şi am analizat manifestarile clinice, tratamentul primit şi factorii prognostici.

Rezultate: $\mathrm{Au}$ fost studiați 42 de pacienți cu GIST dintre care localizare gastrică au fost 23 de cazuri $(54.76 \%)$. Au fost efectuate 7 rezecții pe cale laparoscopică şi 16 intervenții chirurgicale pe cale clasică. Examenul anatomopatologic a arătat o pondere crescută a pacienților din grupele de risc 6a şi 6b (30.43\%). CD 117 a fost pozitiv la $91.3 \%$ din cazuri. In ceea ce priveşte morbiditatea postoperatorie au existat 4 cazuri cu probleme pulmonare, 3 cazuri de infectie plaga postoperatorie şi un caz de hemoragie postoperatorie. Concluzii: Din experiența noastră, intervenția chirurgiclă pentru GIST-urile gastrice trebuie să fie realizată de o echipă bine antrenată, intr-un centru specializat, soluția pentru îmbunătățirea ratei de supraviețuire fiind abordul multidisciplinar ce include un diagnostic cât mai corect, prognosticul de clasificare a riscului şi un tratament corect. 
Cuvinte cheie: tumoră stromală, imunohistochimie, rezecție laparoscopică

\begin{abstract}
Background: Gastrointestinal stromal tumors are some of the most common mesenchymal tumors of the gut. The aim of this study is to asses the clinical manifestation and treatment of gastric GISTs.

Methodology: We performed a retrospective 5-year multicenter study conducted on a prospective collected database, which includes all the patients diagnosed with GIST in which surgery was performed. We selected all the pateients with gastric GISTs and we analyzed the clinical manifestation, treatment and prognostic factors.

Results: There were 42 patients with GISTs of which the gastric GISTs were encountered in 23 cases $(54.76 \%)$. There were 7 laparoscopic resections and 16 open surgery resections. Pathological examination showed that many of the patients were in group 6a and 6b (30.43\%). CD117 was positive in $91.3 \%$ of cases. Regarding postoperative morbidity, there were 4 cases of pulmonary complications, 3 cases of surgical site infection and one postoperative hemorrhage.

Conclusions: In our experience surgery for gastric GIST must be performed by a highly trained team, the keyset for a improved survival is the multidisciplinary approach that includes an accurate diagnosis, prognostic risk stratification and accurate treatment.
\end{abstract}

Key words: stromal tumour, immunohistochemistry, laparoscopic resection

\section{Background}

The gastrointestinal stromal tumours (GIST) are the most frequent non-epithelial tumour of the gastro-intestinal tract $(1,2)$. Although the term of GIST was for the first time used by Mazur and Clark in 1983 (3), this pathological entity was not largely recognized until 1990. CD 34 was the first immunohistochemical marker used for positive and differential diagnosis, some of the main pathological entities that were previous misdiagnosed were: leiomyomas, leiomyosarcomas and schwanomas (4). The annual incidence of symptomatic tumours is 11 to 20 cases per million with a prevalence of 130 per million inhabitants $(1,5)$. Micro GIST (tumours smaller than $1 \mathrm{~cm}$ in diameter) can be found in up to 10 to $22.5 \%$ of the gastrectomy specimens or at autopsies (6, 7 ). The mean age on diagnosis is 63 years and over $80 \%$ of patients are above 50 years, but there were also pediatric cases described in literature (8). Most of the stromal tumours are localized in the stomach (50-60\%) and in the small bowel (30-35\%) and the least common site is the colon (5\%) and esophagus (less than $1 \%)$. It is well known that the stromal tumours do not have a lymphatic spread pattern; the main site of metastases is the liver through hematologic spread. The local recurrence will develop in the omentum or the peritoneal surface (9).

The most common immunohistochemical markers are CD-117 that is positive in over $95 \%$ of tumors and CD34 in 70 to $80 \%$ (10). Less frequents markers are: SMA (smooth muscle actin) in 20 to $30 \%$ of GISTs, desmin in $5 \%$ of cases and in recent years DOG1, also known as ANO1, which is more sensitive than kit antibodies in detecting gastric GISTs especially in tumours with PDGFR alpha mutations (11).

The clinical manifestation of stromal tumours are unspecific, up to $25 \%$ of cases are diagnosed on imaging studies for a different pathology, on a routine endoscopy or during 
surgery. Due to the fact that the tumour can erode the mucosa, the patients are prone to develop gastro-intestinal bleeding and the most common clinical presentation can be acute hematemesis, melaena or chronic anemia (12). Nevertheless, this tumor can cause gastrointestinal obstruction symptoms, weight loss or it can be found as an abdominal mass on clinical examination.

The keysets in the treatment of GIST's are the surgery and the molecular therapy. The aim of the surgical treatment is the complete resection with negative resection margins with limited surgical mobilization of tumor in order to avoid tumour rupture. Whenever it is possible a limited resection is recommended without lymphadenectomy due to the rarity of lymph node spread. The only exception is the Carney triad (the coexistence of gastric GIST, pulmonary chondroma and extra-adrenal paraganglioma), in which case a lymphadenectomy is recommended (13).

Currently there are several risk assessment scales of tumour behavior and also for prediction of recurrence. Among those risk scales, some of the most used are: Fletcher scale designed in 2002 which includes the size of the tumour and the mitotic rate, the Miettinen scale designed in 2006, the TNM classification and the Gold scale, which is one of the most complete and includes the size and location of the tumours and the mitotic rate. Due to the fact that the stromal tumours do not have a lymphatic pattern of extension we consider the TNM scale to have a lower accuracy. The patient's prognosis is related to the tumor size and the mitotic rate; tumors larger than $10 \mathrm{~cm}$ with a high mitotic rate $(>5$ per $50 \mathrm{HPF}$ ) have a higher risk of recurrence and metastatic spread $(14,15)$.

The aim of this study was to present the experience of two independent high volume centers dedicated to gastro-intestinal surgery on a consecutive series of patients that were submitted to surgery for gastric GIST.

\section{Materials and Methods}

We performed a retrospective multicenter study conducted on a prospective collected database that included all the patients diagnosed with stromal tumours between May 2012 and May 2017 in the 1st Surgical Unit of the Regional Institute of Oncology Iasi and the 1st Surgical Unit of the "St. Spiridon" Hospital Iasi. From all the patients included in the database, we selected for the analysis only the patient with resectable stromal tumors in which surgery was performed. We analyzed the patient's clinical manifestations, tumour characteristics, diagnostic methods, surgical technique and intraoperative findings, early postoperative results in terms of morbidity and mortality and also the microscopic and immunohistochemistry findings. In all the patients the diagnosis was suspected on an abdominal tomography and none of our patients had a positive endoscopy biopsy specimen. Although there were, in selected cases, a high clinical suspicion of stromal tumour on initial evaluation, in none of the cases a neoadjuvant treatment was initiated. The main purpose of the surgical treatment was the complete resection of the tumour. We considered to be a R0 resection any histological specimen with negative resection margins and $\mathrm{R} 1$ resection cases in which the resection margin is less than $1 \mathrm{~mm}$ from the tumour margin. In order to have a risk stratification we used the Armed Forces Institute of Pathology (AFIP) risk scale (Table 1) which includes the localization and size of the tumour, the number of mitoses which represents the three most important prognosis factors for the localized stromal tumours (16).

Rates of metastases or tumor-related death in GISTs of the stomach and small intestine by tumors grouped by the mitotic rate and tumor size.

We analyzed 30-day postoperative morbidity and mortality. Based on histopatological findings, all the patients were referred to Oncology Department where based on a multidisciplinary meeting consensus it was initiated the Imatinib $400 \mathrm{mg}$ per day treatment in most of the cases for a period of 2 years. In patients with recurrence a modified dose of Imatinib was used (400 mg twice per day) or it was initiated the Sumatinib treatment. 
Table 1. AFIP criteria for GIST risk assessment

\begin{tabular}{|c|c|c|c|c|c|c|}
\hline \multirow[t]{2}{*}{ Group } & \multicolumn{2}{|c|}{ Tumor parameters } & \multicolumn{4}{|c|}{$\begin{array}{l}\text { Patients with progressive disease during long-term follow-up and } \\
\text { characterization of the risk for metastasis (\%) }\end{array}$} \\
\hline & Dimension & $\begin{array}{l}\text { Mitotic rate } \\
\text { per } 50 \mathrm{HPF}\end{array}$ & $\begin{array}{l}\text { Gastric } \\
\text { GIST }\end{array}$ & $\begin{array}{l}\text { Jejunal and } \\
\text { ileal GIST }\end{array}$ & $\begin{array}{l}\text { Duodenal } \\
\text { GIST }\end{array}$ & $\begin{array}{l}\text { Rectal } \\
\text { GIST }\end{array}$ \\
\hline 1 & $\leq 2 \mathrm{~cm}$ & $\leq 5$ & 0 none & 0 none & 0 none & 0 none \\
\hline 2 & $>2 \leq 5 \mathrm{~cm}$ & $\leq 5$ & 1,9 very low & 4,3 low & 8,3 low & 8,5 low \\
\hline $3 a$ & $>5 \leq 10 \mathrm{~cm}$ & $\leq 5$ & 3,6 low & 24 moderate & & \\
\hline $3 b$ & $>10 \mathrm{~cm}$ & $\leq 5$ & 12 moderate & 52 high & 34 highb & 57c highb \\
\hline 4 & $\leq 2 \mathrm{~cm}$ & $>5$ & $0^{c}$ & $50^{c}$ & d & 54 high \\
\hline 5 & $>2 \leq 5 \mathrm{~cm}$ & $>5$ & 16 moderate & 73 high & 50 high & 52 high \\
\hline $6 a$ & $>5 \leq 10 \mathrm{~cm}$ & $>5$ & 55 high & 85 high & & \\
\hline $6 \mathrm{~b}$ & $>10 \mathrm{~cm}$ & $>5$ & 86 high & 90 high & 86 highb & 71 highb \\
\hline
\end{tabular}

${ }^{a}$ Tumor categories with very small numbers of cases; ${ }^{b}$ Groups $3 \mathrm{a}$ and $3 \mathrm{~b}$ or $6 \mathrm{a}$ and $6 \mathrm{~b}$ are combined in duodenal and rectal GISTs because of the small number of cases; ${ }^{\circ}$ Denotes the tumor categories with very small numbers of cases; ${ }^{\text {d }}$ No tumors of such category were included in the study. Note that small intestinal and other intestinal GISTs show a markedly worse prognosis in many mitotic rate and size categories than gastric GISTs.

GIST: Gastrointestinal stromal tumor; HPF: high-power field.

\section{Results}

During the study period we included in the analysis 42 patients diagnosed with stromal tumours with a mean age of 64,6 years (range 33-94, SD 13,7 years). There were no differences between sexes (23 males and 19 females). The most frequent site was gastric $(n=23,54.76 \%)$, small bowel $(n=14,33.33 \%)$, rectal $(n=3,7.14 \%)$, but there were also 2 cases $(4.76 \%)$ of extradigestive stromal tumours.

The study group which included 23 patients with gastric stromal tumours with a mean age of 62.2 years (range 33-78, SD 10.85). Based on the localization the most frequent site was the upper body of the stomach in 12 patients $(52.18 \%)$, body 8 cases
(34.78\%) and distal stomach 3 patients (13.04\%); results are shown in Table 2.

Regarding the clinical manifestations of patients, the most frequent clinical sign was abdominal pain in 8 cases $(34.8 \%)$, upper digestive hemorrhage in 6 cases $(26.1 \%)$, palpable abdominal mass 3 cases (13\%) and in 6 patients (26.1\%) there was no clinical sign. In patients without symptoms (26.1\%) diagnosis was suspected on abdominal ultrasound. In all patients were performed abdominal ultrasound, abdominal and pelvic tomography and upper digestive endoscopy. Based on the findings on abdominal tomography (tumour development inside the gastric wall or extragastric extension) the diagnosis of gastric stromal tumor was suspicioned in 19 cases

Table 2. Demographic characteristics and tumour localisation

\begin{tabular}{lcccccc} 
Characteristics & $\begin{array}{c}\text { Total number } \\
\mathrm{n}=\mathbf{4 2}\end{array}$ & $\begin{array}{c}\text { Stomach } \\
\mathrm{N}=\mathbf{2 3}\end{array}$ & $\begin{array}{c}\text { Duodenum } \\
\mathrm{N}=\mathbf{2}\end{array}$ & $\begin{array}{c}\text { Small bowel } \\
\mathrm{N}=\mathbf{1 2}\end{array}$ & $\begin{array}{c}\text { Colo-rectal } \\
\mathrm{N}=3\end{array}$ & $\begin{array}{c}\text { Extradigestive } \\
\mathrm{N}=2\end{array}$ \\
\hline Mean age & 64.6 & 62.2 & & \\
\hline female & 19 & 13 & & \\
\hline male & 23 & 10 & \\
\hline Tumour site & 3 & Upper stomach \\
& $n=12$ \\
& Body $n=8$ \\
Distal stomach \\
$n=3$
\end{tabular}


(82.6\%), in all other cases (17.4\%) diagnosis was confirmed only by pathological examination. In this series there was a suspicion of gastric stromal tumour on endoscopy in 15 cases (65.21\%), among those patients 3 were asymptomatic, 4 patients presented abdominal pain, in 2 cases an abdominal mass was found on clinical examination and in 6 cases gastrointestinal bleeding was the initial manifestation. Of those 15 patients, biopsy was performed in 12 cases; in 3 cases lesions found on endoscopy were not considered to be te source of gastric bleeding. In 14 cases (93.33\%) the biopsy results were negative and in one case there was a suspicion of a possible tumour, without positive confirmation.

Patient's characteristics are summarized in Table 3, on admission the mean hemoglobin levels was $10.8 \mathrm{~g} / \mathrm{dl}(7.2-14)$ and albumin levels was $3 \mathrm{~g} / \mathrm{dl}$ (2.3-3.9). Most common comorbidity was: hypertension - 14 cases, diabetes in 9 cases, chronic heart disease -8 cases, COPD - 8 cases, chronic renal failure 3 cases and one female patient was previously treated for a breast cancer.

In all the patients in this study surgery was the first treatment option. Due to the fact that the previous treatment protocols for stromal tumors recommended a positive biopsy for the reimbursement of Imatinib as neoadjuvant treatment, none of the patients were suitable for this protocol. Surgical treatment consisted in laparoscopic resection in 7 cases and open surgery in 16 cases; surgical techniques were: limited/wedge resections 19 cases (in 7 cases laparoscopically and in 12 cases by laparotomy), 3 distal gastrectomies and in one patients with a locally advanced tumour a multiorgan resection was performed (gastrectomy, splenectomy and colon resection).
Table 3. Patient's characteristics

\begin{tabular}{|c|c|c|c|}
\hline & & $\mathrm{Nr}$. & $\%$ \\
\hline \multirow[t]{4}{*}{ Simptoms } & Abdominal pain & 8 & 34.8 \\
\hline & Abdominal mass & 3 & 13 \\
\hline & Gl bleeding & 6 & 26.1 \\
\hline & Without simptoms & 6 & 26.1 \\
\hline \multirow[t]{2}{*}{ HB levels } & $\leq 10.8$ & 9 & 39.13 \\
\hline & $>10.8$ & 14 & 60.87 \\
\hline \multirow[t]{2}{*}{ Albumine } & $\leq 3$ & 13 & 56.52 \\
\hline & $>3$ & 10 & 43.48 \\
\hline \multirow[t]{6}{*}{ Commorbidities } & Hypertension & 14 & 60.87 \\
\hline & Diabetes & 9 & 39.13 \\
\hline & Cardiac disease & 8 & 34.8 \\
\hline & Pulmonary disease & 8 & 34.8 \\
\hline & Cronic renal disease & 3 & 13 \\
\hline & Other cancer & 1 & 4.34 \\
\hline
\end{tabular}

Surgical treatment is summarized in Table 4.

There were no differences regarding the rate of $\mathrm{R}$ resections by comparing the surgical approach (classic vs. laparoscopic resection), this approach was preferred for tumour less than $5 \mathrm{~cm}$ in diameter. Unfortunately in two cases of laparoscopic resection there was a tumor spillage during the dissection.

Pathological examination of resection specimens showed a relatively high number of highly malignant stromal tumours (class 6a of $6 \mathrm{~b})(\mathrm{n}=7$ cases, $30.43 \%)$. Also, there was a relatively equal distribution of cases regarding the other prognostic groups (Table 5).

The specific diagnosis included immunohistochemical staining, in all patients CD117 and CD34 were used as standard diagnostic test; CD117 was positive in over $90 \%$ of patients $(n=21,91.3 \%)$ and CD34 in 19 patients $(82.6 \%)$. Most of the patients $(\mathrm{n}=18,78.26 \%)$ presented a low mitotic index $(\mathrm{Ki} 67<10 \%)$ and 5 patients (21.7\%) a higher index (Ki67>10\%).

Table 4. Surgical intervention

\begin{tabular}{lcccc}
\hline Type of surgery & No. (\%) & Mean time (min) & R0 & R1/tumour rupture \\
\hline Laparoscopic resection & $7(30.43)$ & 88 & 5 & 2 \\
\hdashline Open surgery & $12(52.18)$ & 93 & 11 & 0 \\
\hdashline Distal gastrectomy & $3(13.05)$ & 125 & 3 & 1 \\
\hline Multiorgan resection & $1(4.34)$ & 185 & 0 & 1 \\
\hline
\end{tabular}


Table 5. Distribution of tumours regarding risk stratification

\begin{tabular}{|c|c|c|c|c|c|}
\hline Prognostic group & Risk of metastases & No. of cases & Tumor size (cm) & Mitosis /50 HPF & $\%$ \\
\hline 1 & none & 0 & - & - & 0 \\
\hline \multirow[t]{3}{*}{2} & Very low & 3 & 2.2 & 3 & 13.04 \\
\hline & & & 3.7 & 1 & \\
\hline & & & 5.0 & 4 & \\
\hline \multirow[t]{5}{*}{$3 a$} & Low & 5 & 6.3 & 2 & 21.74 \\
\hline & & & 7.5 & 3 & \\
\hline & & & 7.9 & 2 & \\
\hline & & & 8.3 & 4 & \\
\hline & & & 9.8 & 3 & \\
\hline \multirow[t]{3}{*}{$3 b$} & Moderate & 3 & 26.2 & 4 & 13.04 \\
\hline & & & 13.7 & 2 & \\
\hline & & & 18.3 & 3 & \\
\hline 4 & - & 1 & 1.9 & 6 & 4.36 \\
\hline \multirow[t]{4}{*}{5} & Moderate & 4 & 3.9 & 6 & 17.39 \\
\hline & & & 2.4 & 8 & \\
\hline & & & 4.8 & 8 & \\
\hline & & & 2.8 & 7 & \\
\hline \multirow[t]{4}{*}{$6 a$} & High & 4 & 6.7 & 6 & 17.39 \\
\hline & & & 7.5 & 10 & \\
\hline & & & 8.3 & 8 & \\
\hline & & & 9.4 & 20 & \\
\hline \multirow[t]{3}{*}{$6 \mathrm{~b}$} & High & 3 & 26.4 & 40 & 13.04 \\
\hline & & & 17.5 & 20 & \\
\hline & & & 23.8 & 100 & \\
\hline
\end{tabular}

Regarding postoperative morbidity, 4 patients developed pulmonary complications, 3 patients developed surgical site infection and one patient developed a postoperative hemorrhage that was treated conservatively. Postoperative mortality was in one case in the third postoperative day due to a massive cardiac infarction.

Mean postoperative follow-up period was 19.4 months (6-34 months), tumour recurrence occurred at 24 months in a patient with $\mathrm{R} 1$ resection despite the initiation of Imatinib treatment. There were two cases with R0 resection with recurrences at 28 and 30 months after surgery (Fig. 1).

\section{Discussion}

Although rare, GISTs are more frequently diagnosed and treated due to the high suspicion rates on imaging, with a high chance of cure due to the standardization of surgical technique (limited tumor mobilization during dissection and inefficacity of lymphadenectomy) and the development of specific target drugs that can dramatically reduce the recurrence rates. The most frequent localization of GISTs are in the stomach (17) and this localization gives the patients a better survival as shown in previous studies (15). Moreover there is a

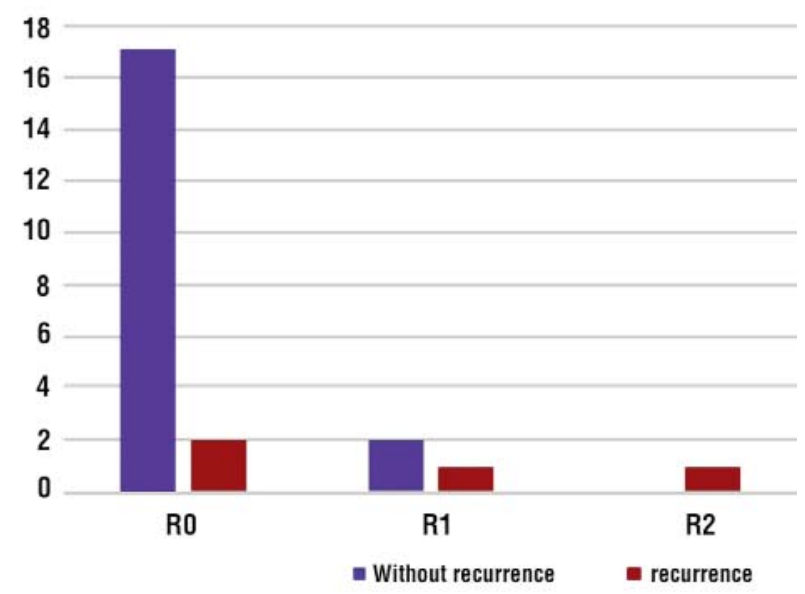

Figure 1. Recurrence based on resection type 
higher incidence of gastric GISTs in the upper third of the stomach, up to $2 / 3$ of cases (18). The results of our studies are similar with the reported percentages of gastric GISTs, most of the cases in our series were located in the upper part and the body of the stomach $(89.66 \%)$, more frequent than the previous reports (18).

Regarding the clinical manifestation of GISTs there is a large panel of symptoms, with a mean interval of 6 months between the first clinical symptom and the diagnosis according to De Matteo (19). In our series the most frequent clinical sign on debut was abdominal pain (34.8\%), followed by GI bleeding (26.1\%) due to the ulceration of the mucosa and the submucosa. Previous studies reported on more than half of the patients symptoms related to anemia caused by GI bleeding (20).

As previous reported (21) there is no ideal stadialisation and prognostic score for GISTs, there are several prognostic scores with relatively high sensibility for recurrence and therefore for the initiation of a treatment protocol. In our study we used the AFIP (Armed Forces Institute of Pathology), which, in our opinion has the highest sensibility. Up to one third of our cases (30.43\%) were classified in the $6 \mathrm{a} / 6 \mathrm{~b}$ stage, mainly due to the large volume of the tumor. The mean diameter of the tumors in our study $(13.2 \mathrm{~cm})$ is relatively high, the reported mean diameters in several studies varies between $1.5-2 \mathrm{~cm}$ (22) up to $18.5 \mathrm{~cm}$ (23); smaller tumors are reported in series which included patients in which laparoscopic surgery was performed, larger tumors in patients with open surgery. In our series we did not had any patients with liver, peritoneal or distant metastases. Most of the patients (75\%) in our series were symptomatic on diagnosis; this can be explained by the larger size of the tumors, previous studies reported a lower percentage of symptomatic patients (50 to $70 \%)(5,12)$. In a study from Mayo clinic non of the patients were symptomatic (22).

Based on the consideration that GISTs are rare tumours and that they have a malignant behavior, we consider that the treatment should be based on a multidisciplinary board recommendation. Prior to introduction of Imatinib treatment the median survival of those patients was 10 to 20 months, the association of this treatment improves survival up to 5 years (24). Actual standard based on previous studies increased the duration of Imatinibe treatment form 1 year up to 3 years (25), although the optimum duration of treatment remains unknown. This treatment is generally well supported by the patients, the most frequent side effects are: anemia, diarrhea, nausea, fatigue and leucopenia. Most of those side effects are well controlled by medication. Genetic analysis of c-kit gene mutation profile has proved to be the best predictor for response to Imatinibe treatment. The best results are in patients with exone 11 mutation (26). Sunitinib is currently approved as second-line treatment in patients with developed resistance on intolerance for Imatinibe treatment, which gives a improved time to progression from 1,5 months to 6.3 months (27). More recently, Regorafenib was approved for third line treatment for patients with advanced GISTs, which developed resistance to either Imatinib or Sorafenib treatment, with an increased mediane of progression free survival from 0.9 months up to 4.8 months (28).

Previous studies regarding the surgical treatment of gastric GISTs recommend that total or subtotal gastrectomy should be performed only in cases in which the tumor invades the cardia or the pylorus (29). Limited resection (wedge type) with negative margins is recommended for most of the gastric GISTs. In our series we performed only limited resections and only in 3 cases a distal gastrectomy due to the volume of the tumor. The indication for laparoscopic resection is small tumors up to $5 \mathrm{~cm}$ in diameter $(22,30)$ but with an increase risk for $\mathrm{R} 1$ resections especially in large tumors.

One of the utmost factors regarding the prognostic of GISTs is the recurrence rate. Residual tumor after surgery is directly correlated with lower survival despite the adjuvant treatment (31). The negative impact of microscopically residual tumor cells 
dramatically impairs the 5 year survival (42\% vs. 9\%) (32). In our study there were 2 early recurrences in patients with $\mathrm{R} 2$ resections (at 4 months postoperatively) or at one year in a patient with $\mathrm{R} 1$ resection. In only 2 cases of $\mathrm{R} 0$ resection without the Imatinib treatment recurrence occurred after 2 years after surgery, this is similar with the reported period in which the recurrence can occur.

This study has several weak points: the lack of a longer postoperative follow-up, the fact that not in all the patients the complete panel of immunohistochemical markers was used and the lack of genetic profile for c-kit mutations. The positive points of our study are that it is a consecutive multicentric study with a relatively uniform diagnostic, treatment and follow-up protocol.

\section{Conclusions}

Based on the results of our study a multidisciplinary treatment protocol should be used in all the patients with a suspicion of gastric GIST on abdominal imaging, the relatively larger tumors impose the use of classic surgical techniques, and the intraoperative limited manipulation either in laparoscopic or open surgery in the key for a lower local recurrence.

\section{Competing Interests}

The authors declare that they have no competing interests.

\section{Author's Contributions}

All authors have an equally contribution to the manuscript.

\section{References}

1. Miettinen M, Majidi M, Lasota J. Pathology and diagnostic criteria of gastrointestinal stromal tumors (GISTs): a review. Eur J Cancer. 2002;38 Suppl 5:S39-51.

2. Goettsch WG, Bos SD, Breekveldt-Postma N, Casparie M, Herings RM, Hogendoorn PC. Incidence of gastrointestinal stromal tumours is underestimated: results of a nation-wide study. Eur $\mathrm{J}$ Cancer. 2005;41(18):2868-72.

3. Mazur MT, Clark HB. Gastric stromal tumors. Reappraisal of histogenesis. Am J Surg Pathol. 1983;7(6):507-19.
4. Miettinen M, Virolainen M, Maarit Sarlomo R. Gastrointestinal stromal tumors--value of CD34 antigen in their identification and separation from true leiomyomas and schwannomas. Am J Surg Pathol. 1995;19(2):207-16.

5. Nilsson B, Bumming P, Meis-Kindblom JM, Oden A, Dortok A, Gustavsson B, et al. Gastrointestinal stromal tumors: the incidence, prevalence, clinical course, and prognostication in the preimatinib mesylate era--a population-based study in western Sweden. Cancer. 2005;103(4):821-9.

6. Abraham SC, Krasinskas AM, Hofstetter WL, Swisher SG, Wu TT. "Seedling" mesenchymal tumors (gastrointestinal stromal tumors and leiomyomas) are common incidental tumors of the esophagogastric junction. Am J Surg Pathol. 2007;31(11):1629-35.

7. Agaimy $A$, Wunsch $P H$, Hofstaedter $F$, Blaszyk H, Rummele $P$, Gaumann A, et al. Minute gastric sclerosing stromal tumors (GIST tumorlets) are common in adults and frequently show C-KIT mutations. Am J Surg Pathol. 2007;31(1):113-20.

8. Miettinen M, Lasota J, Sobin LH. Gastrointestinal stromal tumors of the stomach in children and young adults: a clinicopathologic, immunohistochemical, and molecular genetic study of 44 cases with long-term follow-up and review of the literature. Am J Surg Pathol. 2005;29(10):1373-81.

9. DeMatteo RP, Lewis JJ, Leung D, Mudan SS, Woodruff JM, Brennan MF. Two hundred gastrointestinal stromal tumors: recurrence patterns and prognostic factors for survival. Ann Surg. 2000; 231(1):51-8.

10. Reith JD, Goldblum JR, Lyles RH, Weiss SW. Extragastrointestinal (soft tissue) stromal tumors: an analysis of 48 cases with emphasis on histologic predictors of outcome. Mod Pathol. 2000;13(5):577-85.

11. Lee $\mathrm{CH}$, Liang CW, Espinosa I. The utility of discovered on gastrointestinal stromal tumor 1 (DOG1) antibody in surgical pathology-the GIST of it. Adv Anat Pathol. 2010;17(3):222-32.

12. Caterino S, Lorenzon L, Petrucciani N, Iannicelli E, Pilozzi E, Romiti A, et al. Gastrointestinal stromal tumors: correlation between symptoms at presentation, tumor location and prognostic factors in 47 consecutive patients. World J Surg Oncol. 2011;9:13.

13. Zhang L, Smyrk TC, Young WF, Jr., Stratakis CA, Carney JA. Gastric stromal tumors in Carney triad are different clinically, pathologically, and behaviorally from sporadic gastric gastrointestinal stromal tumors: findings in 104 cases. Am J Surg Pathol. 2010;34(1):53-64.

14. Casali PG, Jost L, Reichardt P, Schlemmer M, Blay JY, Group EGW. Gastrointestinal stromal tumors: ESMO clinical recommendations for diagnosis, treatment and follow-up. Ann Oncol. 2008;19 Suppl 2:ii35-8.

15. Joensuu $H$. Risk stratification of patients diagnosed with gastrointestinal stromal tumor. Hum Pathol. 2008;39(10):1411-9.

16. Group EESNW. Gastrointestinal stromal tumors: ESMO Clinical Practice Guidelines for diagnosis, treatment and follow-up. Ann Oncol. 2012;23 Suppl 7:vii49-55.

17. Soreide K, Sandvik OM, Soreide JA, Giljaca V, Jureckova A, Bulusu VR. Global epidemiology of gastrointestinal stromal tumours (GIST): A systematic review of population-based cohort studies. Cancer Epidemiol. 2016:40:39-46.

18. Matthews BD, Joels CS, Kercher KW, Heniford BT. Gastrointestinal stromal tumors of the stomach. Minerva Chir. 2004;59(3):219-31.

19. DeMatteo RP. The GIST of targeted cancer therapy: a tumor (gastrointestinal stromal tumor), a mutated gene (c-kit), and a molecular inhibitor (STI571). Ann Surg Oncol. 2002;9(9):831-9.

20. Miettinen M, Sobin LH, Lasota J. Gastrointestinal stromal tumors of the stomach: a clinicopathologic, immunohistochemical, and molecular genetic study of 1765 cases with long-term follow-up. Am J Surg Pathol. 2005;29(1):52-68.

21. Predescu D, Gheorghe M, Predoiu I, Iosif C, Constantin A, Chiru F, et al. Gastrointestinal stromal tumor (GIST)--medical rarities?. Chirurgia (Bucur). 2010;105(4):577-85.

22. Huguet KL, Rush RM, Jr., Tessier DJ, Schlinkert RT, Hinder RA, 
Grinberg GG, et al. Laparoscopic gastric gastrointestinal stromal tumor resection: the mayo clinic experience. Arch Surg. 2008; 143(6):587-90; discussion 91

23. Naguib SF, Zaghloul AS, El Marakby H. Gastrointestinal stromal tumors (GIST) of the stomach: retrospective experience with surgical resection at the National Cancer Institute. J Egypt Natl Canc Inst. 2008;20(1):80-9.

24. Joensuu H, Fletcher C, Dimitrijevic S, Silberman S, Roberts P, Demetri G. Management of malignant gastrointestinal stromal tumours. Lancet Oncol. 2002;3(11):655-64.

25. Joensuu H, DeMatteo RP. The management of gastrointestinal stromal tumors: a model for targeted and multidisciplinary therapy of malignancy. Annu Rev Med. 2012;63:247-58.

26. Corless CL, Barnett CM, Heinrich MC. Gastrointestinal stromal tumours: origin and molecular oncology. Nat Rev Cancer. 2011;11(12):865-78.

27. Demetri GD. Differential properties of current tyrosine kinase inhibitors in gastrointestinal stromal tumors. Semin Oncol. 2011;38 Suppl 1:S10-9.
28. Demetri GD, Reichardt P, Kang YK, Blay JY, Rutkowski P, Gelderblom $\mathrm{H}$, et al. Efficacy and safety of regorafenib for advanced gastrointestinal stromal tumours after failure of imatinib and sunitinib (GRID): an international, multicentre, randomised, placebo-controlled, phase 3 trial. Lancet. 2013; 381(9863):295-302.

29. Bucher P, Villiger P, Egger JF, Buhler LH, Morel P. Management of gastrointestinal stromal tumors: from diagnosis to treatment. Swiss Med Wkly. 2004;134(11-12):145-53.

30. Nishimura J, Nakajima K, Omori T, Takahashi T, Nishitani A, Ito T, et al. Surgical strategy for gastric gastrointestinal stromal tumors: laparoscopic vs. open resection. Surg Endosc. 2007; 21(6):875-8.

31. Boni L, Benevento A, Dionigi G, Rovera F, Dionigi R. Surgical resection for gastrointestinal stromal tumors (GIST): experience on 25 patients. World J Surg Oncol. 2005;3:78.

32. Pierie JP, Choudry U, Muzikansky A, Yeap BY, Souba WW, Ott MJ. The effect of surgery and grade on outcome of gastrointestinal stromal tumors. Arch Surg. 2001;136(4):383-9. 